Notre Dame Law School

NDLScholarship

Natural Law Forum

$1-1-1962$

\title{
Personal Response and the Natural Law
}

M. G. Plattel

Follow this and additional works at: http://scholarship.law.nd.edu/nd_naturallaw_forum

Part of the Law Commons

\section{Recommended Citation}

Plattel, M. G., "Personal Response and the Natural Law" (1962). Natural Law Forum. Paper 70.

http://scholarship.law.nd.edu/nd_naturallaw_forum/70

This Article is brought to you for free and open access by NDLScholarship. It has been accepted for inclusion in Natural Law Forum by an authorized administrator of NDLScholarship. For more information, please contact lawdr@nd.edu. 


\title{
PERSONAL RESPONSE AND \\ THE NATURAL LAW
}

\author{
M. G. Plattel
}

CONTEMPORARY society has acquired a dynamic character through the development of science and technique. In our technical age it sometimes looks as if continuous change is the only thing which does not change. Man realizes that his own humanity is subject to evolution. Hence a pinching question arises: Does man's ethics still possess an absolute validity and an immutable foundation? Thinkers representing different trends in contemporary philosophy are critical of the old moral conceptions. Personalist philosophers stress the uniqueness of every person and maintain that traditional ethics is too uniform and too little applicable to the particular situation. Existentialism enters a protest against the unauthenticity of the lives of the impersonal masses. It judges the traditional morals as heteronomous and as therefore fostering unauthenticity. It emphasizes that the ultimate norms for moral behavior stem from personal freedom and personal conscience.

These different trends in modern philosophy pose the problem of whether the traditional natural law ethics is still of value for our time. In what follows I wish to deal with this problem and to confront the theory of natural law with some present tendencies in ethical thinking.

\section{The Natural Law as "Idea" and as "Doctrine"}

IN GENERAL the concept of natural law elicits the thought of a totality of norms that govern the actions of man and society. The concept of natural law reflects the attempt to protect law and morals from human arbitrariness and to give them absolute validity. In this attempt nature is conceived of as an absolute reality which determines man's behavior.

In traditional treatments the natural law is technically described as the theoretical and generally valid principles deriving from the nature of man or society. These universal principles are considered to possess absolute, immutable, and supratemporal value. At the same time general principles, by virtue of their very abstractness, are considered to require embodiment in the concrete. This means that the concrete circumstances of place and time have to be considered when putting principles into practice. Concrete acts must be evaluated in the enlightening intelligibility of these basic principles. 
The concrete and hence variable application should remain within the orbit of the immutable principles and may not impair them.

This traditional approach distinguishes sharply between the immutable, supratemporal natural principles and their application to the historical situation. Modern philosophy rightfully objects to such a one-sided, conceptual mode of thought. It is exactly man's involvement in history which forms a central theme in modern philosophic thinking. Traditional natural law theory likewise assumes a historical element in man. This element, however, is understood more as a condition, an external, though important, phenomenon which determines the person from outside. But involvement in history goes deeper and affects the entire person in his very being. The natural law in the traditional sense is considered far too much as an ahistorical category.

Men have all too often propounded a univocal concept of natural law which was closely associated with an antiquated cultural pattern. It has been assumed that man existed in a "given" world order of immutable and supratemporal entities, from the appearance of which he would be able to deduce, from without, the human norm for his actions. In addition, human nature was largely understood as an "object," and the norms which resulted from this "object" were placed in an objectivistic, independent order, a monde-en-soi. The natural law was thus too easily used. as an "object at hand."

A conservative influence emanated from this immutable and eternal order to which man had to conform. This past mode of thought makes an unnatural and unreal impression, since man's involvement in history is increasingly emphasized by the accelerating growth of his culture. It cannot be stressed sufficiently that human nature is a free nature. Man, as a person, possesses an irreplaceable originality. This originality does not imply that as a person he confers upon the world and upon himself an arbitrary meaning. Human freedom - a finite and participating freedom - involves being bound by values. It is precisely in intersubjective human relationships that man paradoxically finds his highest freedom in being totally bound and yet totally free.

This emphasis on personal intrinsic value does not involve a relativist subjectivism, because, no matter how contradictory this may sound, human beings are in fact equal in their very inequality. We are here concerned with the concrete universality of absolute values such as love, faithfulness, freedom, which can only be expressed in analogous, universal ideas. They cannot be applied as principles of the natural law in the sense of univocal, uniform norms. These values are immanent in men, and by virtue of this immanence transcend man. Insofar as man has a corporal nature he can be 
classified as a "species," and in this regard we can speak of a certain uniform, universal "human condition." By this we mean determining factors which are biological, psychological, and sociological. It is particularly these corporal levels of personal being which can be formulated in terms of a more explicit body of uniform norms and legal regulations. But since we are dealing with a spiritualized corporal nature, we must likewise stress the existentiality of this uniform structure. Indeed the person must function within biological and psychological limitations which color his being, but he is called to make these given corporal qualities part of his personal, free existence.

The greater the spiritual content of human values, the less these values can be expressed in a univocal conceptual manner, and the more they must be expressed in an analogous ideal manner. There exists a certain inverse proportionality between nature as a concrete existential reality and nature as approached in a univocal conceptual manner. The more something belongs to the essence of personal being, i.e., to the essence of spiritual being, the less it can be considered in the light of a univocal conceptual formulation of the natural law. Rather, it is known intuitively and spontaneously, although its expression in a concept - albeit in an analogous ideal-concept - cannot be dispensed with. ${ }^{1}$ The more, however, something is capable of being univocally defined, the less one is dealing with those values which touch upon the essence of personal being. Then we are speaking of the biological rather than the spiritual nature of man. Thus there exists a certain inverse proportionality between nature as intuitively known and nature as univocally conceived.

The human person as an incarnate spirit is historical, that is, supratemporal in a temporal order, unchangeable in changeability. Both elements completely interpenetrate each other and cannot be separated. From this fact it follows that the distinction between natural law as an immutable law, and positive law as a changeable law, must be used with caution. ${ }^{2}$ We are dealing here. with a tentative, conceptual, and retrospective systematization of

1. Univocal-universal concepts are ordered logically according to genus and species. They should be distinguished from analogous-universal ideas or concepts, which are called transcendentals. Between the two extremes of univocal concepts and analogous-universal ideas all sorts of intermediary forms exist. The univocal meaning of a concept is most clearly prevalent in the material realm where we talk of individuals of the species. Thus, insofar as we can speak of man as a corporal being, the univocal concept applies to a certain extent. But concepts which are related to man as a spiritual being are analogous ideal-concepts. Man as a spiritual person is not an individual of the species, but in this view he is a species all by itself. With regard to man as a spiritual person, a univocal repetition of the same abstract species is out of the question; we are rather concerned with an intrinsic repetition of the analogous idea of species. Cf. J. Peters, Metaphysics 279-280 (1957); M. G. Plattel, 1 Sociale Wijsbegerre: De Mens en het Medemenselijke 21-24 (2nd ed., 1960). 2. Cf. C. Bronkhorst, Recht en Wereld, 17 Tijdschrift voor Prilosophie 591-620 (1955). 
the one historical reality; outside of this systematization the above distinction makes no sense whatsoever. The natural law as an objective totality, contained in univocal concepts and composed of rules, possesses an element of changeability; in this sense it can already be called positive law. However, insofar as the norms of the natural law tend to refer to absolute value, they also share in this value and hence are unchangeable. Positive law, on the other hand, is not purely changeable; if it were, it would be subhuman. It is only brute material reality that changes. Positive law shares, no matter how remotely, in absolute justice, and for this reason must be "respected." Thus in its turn positive law could also be called natural law, but in a restricted sense.

The idea of a natural law as an ahistorical reality, which in its supratemporality and immutability could be completely known by man in explicit concepts, is to be rejected. Man does not possess an "all-surveying" vision, a regard survolant; as a limited "situated" person, he can only become conscious of the absolute ideal. If natural law is conceived, according to an idealistic pattern, as a known ahistorical reality, it degenerates into an object at man's command. However, man does not have this reality at his disposal, as natural law dogmatists wrongly believe.

The advocates of such a rationalistic conception oftentimes reproach the proponents of a "historical" natural law with ethical relativism. This objection is unfounded and should rather be addressed to these dogmatists themselves. Historicity is sometimes too easily identified with pure relativism and arbitrariness. True historicity originates exactly in virtue of a transhistorical reality. The historical aspect includes an aspect of the absolute, which indeed cannot be isolated from the temporal, but from which nevertheless our total historical existence derives its ascending dynamics and meaning. It is precisely because the moral ideal possesses such a transcendent value that man can participate in it evermore fully only by his growth and searching though the centuries, so that natural law is never completed, but rather always discovered more deeply. Precisely through man's perceiving of what is relative in the natural law, he transcends relativism and touches upon moral reality in the absolute. It is the rationalist who makes his relative conception of the natural law into the "immutable natural law," and thus seals it off from any further growth. This conceptualism, which in fact identifies what is relative with the absolute, is itself the grossest form of relativism. The more the historical perspective and evolutionary nature of the natural law comes to the fore, the more profound the apprehension of transcendent truth will become. This development does not imply that our knowledge of the natural law changes in the univocal sense of forever becoming different. 
Our historical consciousness implies precisely an all-pervading orientation beyond history. Knowledge of the natural law by ideal-concepts does not so much change as grow. Only insofar as we intentionally touch upon the absolute by way of conceptual structures - with their material and spatial symbols - can we speak to a certain degree of change; the concept now appears in all its poverty. Insofar, however, as the concept is the expression of that which is known intuitively - in its richness as ideal-concept - we touch upon moral reality in its absoluteness, but in a way which demands a continued growth toward truth.

Existential ethics emphasizes the concrete universality of the moral ideal which every person ought to fashion individually and at the same time in an analogous, universal manner. This ethics expresses itself particularly in ideal-concepts. Thus expressed, existential ethics lacks the logical, univocal lucidity of a natural law which bases itself on the nature of man and society considered in their character of "object," but this logical pseudo-lucidity is transcended in personalist ethics by the suprarational light of the authentic ethical consciousness. It is true that man, because of the determined aspect of his being, continues to need practical norms which are imposed on him from outside. Human intuition still needs to be clarified in concepts. However, a truly ethical man will not so much perceive these norms in their objective aspects as view them as existent symbolic actualizations of the concrete-universal ideal of man, which is realized in the personal union of love.

The natural law cannot be absolutely proved according to the canons of positive knowledge, since we are not dealing with a material reality. There exists, to a certain degree, the possibility of rendering a rational account according to the degrees of perfection which the natural law expresses. The more, however, we are concerned with spiritual values, the less scientific verification applies. Besides, on this higher level, the need for this verification constantly decreases. Spiritual realities are known through a believing and loving attitude; in other words, through the light of human subjectivity itself. Cognizance of the natural law is impossible without an act of faith. ${ }^{3}$ This form of belief belongs to a different order of things than that of knowing "objective" reality. In the case of rational scientific knowledge, faith and knowledge are indeed opposite entities. If man knows anything on the level of science, he no longer believes; and if he believes on this level, then he has not yet attained to knowledge. On this level, faith is indeed a lesser form of knowledge. However, in knowing a spiritual reality, faith and knowledge must not be understood according to the univocal manner of scientific knowledge. Here,

3. C.. Plattel, op. cit. supta note 1 , at 33-37; also A. Brunner, Glaube und EreenntN1s 71-81 (1951). 
faith and knowledge are not inversely proportionate. Whereas faith on the rational scientific level results from my knowing so very little, faith in the spiritual reality results from my knowing so very much. In this context, faith does not occupy the place of knowledge, and knowledge does not occupy the place of faith. On this level, my believing is a knowing believing; my knowing, a believing knowing. One errs if one poses the problem of "faith or knowledge" in regard to the knowing of spiritual reality. ${ }^{4}$

The person discovers the natural law as a value from the vantage point of his freedom. In this sense, the law's values are subjective and immanent. However, the more ethically a person lives in meaningful freedom, the more he is aware that the absolute is more immanent in him than he is in himself. He experiences his freedom as a loving answer to the person of another and to the Absolute Other One. Hence, a possible reproach that a personalist ethics is subjective in the sense of being arbitrary appears unjustified. Many misunderstandings arise because "subjective" and "objective" are oftentimes understood ambiguously. If one puts the question whether ethical values are objective or subjective, one must carefully qualify one's answer, because the terms used should not be understood in their univocal physical sense, but in their spiritual analogous interpretation. But this analogous interpretation can, in turn, only come into being by making use of a certain univalence inherent in the external world; and this univalence, in turn, must be corrected.

If the term "objective" is understood univocally - in the same manner as the material world imposes itself upon man in a determining way as an externally given factor - then this term cannot be used in expressing moral values, since only the person himself as a free subject must fashion such values. In this sense ethics is indeed subjective. Conversely, if one understands the term "subjective" as univocally referring to a subject who can deal with a material object arbitrarily and freely, then it must be emphasized that the values are objective. The person does not create the values; rather, the values determine him. No matter how paradoxical it may sound, a wellbalanced personalist ethics is subjective because it is objective, and it bears the mark of objectivity by virtue of its true "subjectivity." This paradox exists because the natural law is an analogous ideal-concept which - in the course of time and varying with the person - is realized again and again in a different, yet similar, manner. To state it once more: the natural law as an analogous ideal-concept does not change in a univocal sense, and hence the idea of an ethical relativism is definitely out of the question.

4. Cf. M. G. Platerl, 1 Socinle Wijgegoegrte: De Mens en het Medemgnselijee 33-36 (2nd ed., 1960). 
II. The Maxims of the Natural Law in their Rrchness and Poverty

The ATTEMPT to formulate ethical reality in terms of natural law precepts remains meaningful and necessary on condition that rational understanding stays in touch with spontaneous consciousness. The implicit, intuitive moral consciousness must be rendered explicit in principles in order to take on reality. In this respect we may speak of the richness of the maxims. On the other hand, the conceptual appropriation of the principles will always remain imperfect; and seen in this light, the principles manifest a faulty character and signify impoverishment. This impoverishment can be counteracted by constantly keeping the precepts of natural law in touch with spontaneous feelings and reactions. These precepts must not be too much employed as a priori insights used to explain historical realities from without. Moreover, if the principles are too much separated from their historical context and from practice, they wither to the level of abstract and empty categories. Thus the norms of love and respect if divorced from every ethical experience constitute an empty formula.

Should the principles in their conceptual expression be severed anyhow from the experience and be taken as lucid perceptions, the result will be that the external historical actualization of the values will be particularly emphasized. Especially insofar as social principles are concerned, this result leads to a strong conservatism. Since an intuitive, absolute element is inherent in human knowledge, that which is externally perceived will be treated as absolute by such a conceptual mode of comprehension. The transcendent ethical reality will then be sealed off in a chunk of historical reality, as often happened, for example, in the case of the principle of private property. If new situations are judged on the basis of such principles, one will necessarily undershoot one's màrk. This new situation will not be evaluated from the standpoint of transcendent values, but from the standpoint of norms which too largely bear the stamp of the past. How often has it not happened that in regard to social matters urgent reforms have been delayed in the name of an immutable divine law?

Neither should we make too rational a distinction between the principles on the one hand and their application to reality on the other, especially if such a distinction then implies primarily a one-way direction from the principles to the applications. The relationship between the principle and a particular case should be understood as that of background and figure. Just as the background appears behind the figure as present but also absent, so one recognizes the principle behind the factual circumstances. On the other hand, as the figure stands out against the background, so the factual circumstances 
appear meaningful only in the light of the principle. An enriching dynamic relation must persist continuously between both.

If the natural law is grasped in a purely univocal concept, this will easily lead to a minimizing of its values. The abstractive method seeks what is uniformly common. The criterion is: what is not present in all subjects should not be included in the description of their essence. In this way what is valid for everyone at the level of a common denominator is taken as essential natural law. In the existentialist vision, however, the natural law grows with the increase of the moral sense.

By continually visualizing the principles as ideal-values, one can avoid also the rationalist pseudo-problem as to how one elementary principle can come into conflict with another. The conceptual method has a divisive character and contrasts the various precepts of the natural law with one another as distinctly separate entities which then must be brought into harmony. In a conflicting situation it is supposed that one principle dispenses a person from adherence to another. According to this approach, for instance, the doctrine of private property is modified by the correction that numerous social obligations are attached to private property. When, however, the concrete-intuitive experience also plays its role actively and participates in conceptualization, concept and experience converge, and a retroactive modification need not be made. The integration takes place from within. The distinct principles then represent the many-sided features of the one moral ideal, which is ultimately expressed in the formulation - which is at once conceptually meaningless, and hence intuitively in all respects meaningful -: do what is right for the other person in this world for the sake of the Absolute Other One. When a principle is conceived as an ideal-value, all integrating tendencies towards the other ideal-norms automatically come to the fore. It is precisely this integrating tendency towards identity with the moral ideal, towards total union in love, which invests the norms with moral values. Thus it is not necessary, for instance, that a possible theory of private property based on the natural law be modified in retrospect by the principle of social responsibility. The proprietary right in its ideal-value visualizes property against the background of human relations. The owner's subjective right is then seen as an intersubjective one.

\section{The Natural Law in its Shifting Historical Interpretations}

The various interpretations of the natural law are intimately bound up with the various shades of meaning attached to the term "nature" during different cultural periods. Nature is not an immutable and fixed entity. The 
concept of it undergoes changes which are contingent upon man's attitude toward it. This evolving concept emerges in historical perspective. There exists an interconnection between man and nature: nature is related to man, and man is always related to nature. Nature and man constitute correlative entities that are mutually explanatory. The different meanings of "nature" result from the fact that man is called to cultivate nature. On the one hand, man employs nature as an "object"; on the other, he realizes that he is immersed in nature and participates in it. The relationship between nature as object and nature as origin is characterized by the dialectics of background and figure. Nature as a horizon is not the external framework of nature as an object, but causes nature as an object to come to the fore. Conversely, only from the viewpoint of nature as an object does nature as a horizon become clearly visible. Between these two mutually complementary polarities, nature as origin and nature as object, the different interpretations of nature oscillate. Man becomes aware of nature as origin to the extent that he succeeds in bringing nature as object to the front; yet this delimitation of nature as object always possesses only tentative validity, because it is achieved within the horizon of nature as origin whose boundaries can never be completely objectified. The manifold interpretations of the concept of nature are thus closely bound up with man's changing attitude with regard to nature. In other words, the concept of nature varies with the history of culture.

The natural law, which considers nature as the origin and fountainhead of ethical standards and legal norms, shows in its historical development a constant shifting of perspective which is contingent upon man's changing attitude toward nature as an object. In the following presentation of some of these shifts in interpretation we should never lose sight of the unchanging identity of natural law exactly insofar as it is the expression of the absolute ethical ideal.

Nature in the primitive world-view possesses a more sacred and normative character than in our cultural climate. Primitive man experiences nature as an absolute, mysterious reality which eludes man's controlling power. Despite the differences in mentality existing among the primitives, a number of general characteristics can be noted.

The primitive mentality is characterized by a nondifferentiating experiencing of all aspects of life. The sacred and the profane, the personal and the social, the inner and the exterior worlds are most intimately and indistinguishably blended. The primitive mind does not at all - or at most, very vaguely - distinguish between the various categories of life such as space and time, the part and the whole, objects and their properties. It is difficult to imagine such a primitive world-view from the standpoint of modern 
man's world of sharply distinct categories. Nature, which to the technical man has become an object that can be controlled and put to use, is to the primitive man a mysterious sacred power. To him it is the Origin, Being, and Becoming of everything, of himself as well as the universe. It reveals itself in man and in the realities around him as a numinous force. The manyfaceted dependence on nature is experienced as a dependence on mysterious divine powers. Even the soul which belongs to man appears as an inscrutable divine force which dominates man. This all-embracing nature bears for the primitive always an essentially sacred character. That is why every striking aspect of nature is surrounded with a religious ritual. All the cosmic happenings, such as the lunar phases, the solstices, light and darkness, the succession of the seasons, are observed and celebrated. Also the human physiological functions, such as feeding, eating, sleeping, defecating, copulating, constitute a participation in a sacred natural order. Nature virtually possesses a supernatural quality; yet, the supernatural is still completely situated in the world, the here and now, the diesseits: The primitive's religious approach is not as yet purely spiritual and supernatural, because nature is not yet material and profane.

In primitive mentality this mysterious nature from which everything takes its being, is "prior" to man, but this "prior" does not mean a past time in our sense of the word. It is a mythical time - to our conception an atemporal one - in which past, present, and future intermingle in undifferentiated fashion. Its "in illo tempore" cannot be described in terms of our time categories. Primitive man continually longs to participate in the constant rejuvenation of nature. The principal events of his life are therefore encompassed by initiation rites. In these rites he dies in order to be born anew, and in so doing he becomes one with nature.

The primitive's entire life is determined in religiously normative fashion by this "supernatural" nature. The traditional customs and habits possess a profoundly religious meaning and are accepted without question, so that they need no rational proof. Since this nature embraces and guides everything, all of society is ruled by its "demonic" authority. In this primitive acceptance of life, the natural, ethical, and religious dimensions constitute one and the same reality.

Vestiges of such a mythical mentality can still be found in early. Greek man. The Greek epic teaches us that the sacred and the profane spheres of life were experienced in an undifferentiated way. However, the culture of Hellas gradually outgrew the realm of myth and magic. The Greek thinkers embarked upon explaining the universe rationally and they attempted to penetrate into the natural order. These philosophers began to express their 
thoughts on the universe in logical instead of mythological terms. Through this first attempt at objectivation man gradually began to place nature opposite to himself, and the religious aspect was pushed into the background. This objectivation of nature also entailed an objectivation of man, who still belonged to nature. More and more, nature came to be understood as a reality that existed independently and in itself. Pre-Socratic philosophy searched for the first principle that would encompass the many entities and at the same time was their very origin and essence. Behind the multiplicity of the phenomena the philosophers attempted to discover a unifying eternal principle which they called nature. One thinker saw this eternal principle as water, another as light, and again another as number.

Greek thought kept pace with the general progress of society. Because man began to interfere more and more actively in the existing world order, the traditional ethos began to lose its mythical character. When, through the development of crafts the city-state came into being and the citizens started making their own laws, a crisis occurred in the realm of the commonly accepted certainties. The existing world-view lost its self-evident religious character and became secularized: the new polis with its own government and laws was felt to be a purely human concern. Moreover, the contact with nations that held different views and customs caused a notion of relativeness to gain ever-wider acceptance. Typical of the changed outlook of this period was the Sophists' distinction between laws that were valid physei, "by nature," and laws that were valid nomooi, "by agreement." The age compelled man to begin contemplating the origin and the content of the norms that were to sustain order among men and in society. The philosophers searched for the eternal and immutable in the multiplicity of phenomena and believed that the universe was governed by law and not by chance.

Man proved himself capable of gaining insight into the harmonious inner order prevailing in nature and within himself. The ancient mythological world-view was based on the capricious and arbitrary power of the gods, which, in turn, reflected primitive man's defenseless and dependent position in nature. Although this archaic "cosmology" was replaced by the concept of a rational and beautifully ordered cosmos, nature itself remained of a higher order. Life was based upon a nature that was no longer divine in itself but was nevertheless visualized as a higher law of life. Through the philosophies of Socrates, Plato, and Aristotle the divine logos became more and more a cosmic rationality and necessity which permeated nature as well as human consciousness. Thus there arose in antiquity the doctrine of the natural law as the expression of this rational cosmic order. The. Greek and subsequently the Roman world continued to express great diffidence 
and respect for this natural law as a norm for man's actions. According to the Stoa, leading one's life in accordance with the laws of nature remained an absolute ethical norm safeguarded from every human whim. In antiquity logos, cosmos, nature, and law were intimately bound up with one another.

The medieval outlook bore great resemblance to the Greco-Roman worldview. Yet during this period man succeeded in putting himself at a certain distance from nature by overcoming somewhat his dependence upon it. In this way he was able to gain for himself a margin of freedom. But even at this time man did not advance in his technical ability beyond the application of those laws in which nature revealed itself. He was able to use only those forces which were volunteered, so to speak, by nature. Some harnessing of nature occurred, but its extent remained quite limited and insignificant. The feudal relationships had naturally grown out of the ancient tribal associations, and urban society was founded on a natural division of labor. Life took place according to a familiar, stable pattern which was therefore looked upon as natural.

Yet here too arose the need for renewed reflection on the norms of life which man needed in order to control and keep pace with his increasing involvement in the secular. Medieval philosophy fell back on Greek cosmic philosophy and on the concept of the natural law inspired by it. At the same time Christianity placed the task imposed on man in a more meaningful light. Greek culture envisioned the human ideal too much in the perspective of earthly existence; the religious aspect was still too closely identified with the profane. It should be remembered that virtue in the stoic sense consisted in the imitation and affirmation of the cosmic necessity and rationality to which all things, including man, were subject. Belief in a personal, transcendent God, who freely created man and the world, increased the value of both world and man. The Christian religion attributed to man a unique value, because he was called to serve God in a personal relationship. A supernatural dimension was bestowed upon human dignity. The universe, being God's creation, was also designated as good; and to man was assigned the task of bringing this goodness to completion. In this manner the world shared in the Christian eschatology. 5

During the Middle Ages the mythical attitude towards life was supplanted by a philosophical-contemplative world-view. The universe, again understood in terms of a reality governed by immutable laws, was at the same time envisioned by theocentric medieval thinkers as a static reflection

5. Cf. A. van Melsen, Natuurwetenschap en Teghiek 192-194 (1960). 
of the eternal divine order. It was conceived as a unified hierarchy within the framework of which man and society were assigned a pre-established position. Everything inside as well as outside man was traced back to a given nature as an objective order of things. By means of logical reasoning man attempted to infer the immanent divine order. In contrast with contemporary views, nature in this period was conceived of in a strongly objectivist vein. This given nature was the revelation of being, the norm of knowledge, and the code of conduct. In this world-view based on the physical, the natural order was considered to be the prototype of all order. Even God Himself, being the primordial cause of this order, was preferably named the prime ruler, the unmoved mover and the eternal law. The revival of Roman law, through the efforts of jurists and theologians, particularly brought out the dual nature of the medieval position. On the one hand, linking up with the past, it attempted to create a suitable foundation for the mythical-religious conception of life; on the other, it attempted to take hold of the newly arisen situations in a normative way. ${ }^{6}$ The more conservative current of thought, based on Ulpian's formulation of the natural law, sought to found life on an objectively given natural law which pertained to all living beings in common, animals as well as human beings. The other trend stemmed from human attempts to render nature subservient to man's designs; it understood the natural law as a typically human order which as such was known solely by man. Both views continued to recognize the lex aeterna as the supreme normative principle and the archetype of all natural law.

With the growth of the cities through the expansion of crafts and commerce, new social structures arose for which neither the criteria and guiding principles of the family relationship nor the traditions of the feudal system could provide the philosophical and spiritual foundation. There grew a need for a legislating and organizing authority which was in a position to impose norms upon the members of the community, although the law during this period was not yet a sovereign law imposed from above. The Middle Ages were still engaged in solving the juridical problem from the vantage point of an objectively given order. The mythical spirit developed into the more rational, logical principle of the common weal. The common weal gave suitable natural legitimation from the viewpoint of natural law to the social relationships which had come into being through crafts and commerce. Legislative authority still concerned itself primarily with the social justification of situations which had naturally developed. The stress on tran-

6. Cf. J. J. Loeff, Het Naturrecht en de Ontwikkeling in het ethisch Denken, 3 Soculs WBTENSGHAPPEN 9-14 (1959). 
quility of order as the highest social principle of natural law resulted from the still predominantly static character of medieval society. The desire for order did not go beyond sanctioning that which already contained an element of order. Law was more customary law than legislative law. It was not so much oriented toward the unique intrinsic value of the person himself as towards the protection of socially acquired privileges. We can speak of a corporative rather than of a personal law, since human interrelationships bore an intercorporative rather than an interpersonal character. One still perceives below the surface even during this period the cosmic substructure of life. In the Middle Ages, man still felt himself bound by the immutable laws of the cosmos which in its harmonious order referred to God.

The Greek and medieval attitude towards life which derived its security from a natural order embracing all men and all things was increasingly shaken when in the modern era man made nature more and more subservient to himself. Through the natural sciences of the sixteenth and seventeenth centuries, logical; systematizing reason developed into calculating, measuring reason. With Descartes, Copernicus, Pascal, and others, the concept of infinity invaded the closed sphere of human life. With the rise of the natural sciences man's attitude towards nature assumed a dynamic, creative character. From the feudal relationships arose, in the postmedieval period, the national states which came to concern themselves more and more with technical and economic problems. The idea of the welfare state grew and with a greater centralization of government became necessary.

The medieval concept of organic unity, according to which the several corporate units were interrelated "by nature," increasingly ceased to correspond to the developing situation. The corporative and feudal relationships lost their strength. In the place of an organic concept of state and society arose the idea of a rational order promoted by the central authority of the state. The Greco-Roman and the medieval world tended to view man as a nature among many natures, at one with the cosmos. Their emphasis was on the universe as a totality of which man is a part. In modern times, man emerged from the familiar cosmic shell and attempted to design his own universe. He viewed himself in opposition to nature, which as an "object" was capable of being manipulated at will. Undoubtedly man had always looked upon nature as an object of exploration. But whereas formerly only those aspects of nature were cultivated that invited use, man now abandoned his passive attitude and dauntlessly attempted to appropriate to himself all of nature as an object. This led, on the one hand, to a greater awakening of the "self" and a confrontation with nature as a "non-self." On the other hand, every further objectivation of nature came to signify also an objec- 
tivation of human nature itself within the scope of scientific investigation.

Because modern man became conscious of his own self by viewing himself and nature as opposites, the human image acquired a curious schizoid character. On the one hand, in his natural strivings man felt himself to be in harmony with nature and became himself the object of the sciences. This tendency led to empiricism. On the other hand, in the capacity of an organizing, ordering being, he felt himself to be distinct from, and elevated above, this reality which he could master. This view led to a greater emphasis on human subjectivity. Since man's awakening took place as to nature and not as to his fellow man, as is happening in our time, this "subjectivity" was characterized by an individualistic rationalism. Already with Descartes the schizoid image of man began to come into prominence, as in his philosophy spirit and matter were understood as two dualistically opposed realities.

The natural law concepts mirrored the changes described above. While the Middle Ages had visualized the natural law as a reflection of the eternal law, God as nature's lawgiver was now pushed into the background. As man's abilities increased, the natural order increasingly lost its sacred character. To be sure, philosophers such as Hugo Grotius still recognized God as the origin of the laws that governed the universe, but after the divine act of creation the natural order was considered to lead an independent existence. Thus the natural law was reduced to a purely immanent order of the universe, and hence was secularized. Whereas the Middle Ages recognized a natural law which man could rationally derive from an objectively given world-order, such realism and objectivism lost its appeal in the face of the new conditions. The nominalism of the Middle Ages began to replace this "realistic" natural law with the subjectivist principle of the human will which in time adopted social expediency as its lodestar. This rationalistic principle of volition was better suited to the changed circumstances that forced Western man to build up the world according to his own image.

The medieval harmany of the spheres was upset, and the individual parts gravitated towards their own sovereignty. Natural law nominalism led, therefore, to the exaggerated individualism of the citizen and to an absolute and unlimited sovereignty of the state. There no longer existed a stable objective order which united both. The only way in which the two could be balanced was by the principle of contract, and in time this principle was degraded to a purely arbitrary and formalistic device.

The natural law theory of the seventeenth and eighteenth centuries was characterized by the conflict between these two spheres. The growing national states found their justification in Machiavelli's theory of Staatsraison as the formulative principle of the power-state and in Bodin's theory of sovereignty 
which placed the authority of the state above the law. The new natural law principles of government became more and more formal constructions and increasingly lost their material content. They often served the purpose of logical justification of the absolute power of the rulers whose tasks became less static, less the administration of justice, and more legislative and dynamic. Meanwhile natural law nominalism still attempted to safeguard the citizen's inalienable liberties. This attempt evolved into a drawing of lines "against" the state, as the idea of a harmonious given order between the spheres of private law and public law steadily lost its value. This led to an individualistic conception of natural law, as with Locke, Wolf, and others, in which there was hardly room for genuine communal law. ${ }^{7}$

The nominalist conceptions of natural law were developed in a rationalistic as well as in an empirical direction by philosophies in these centuries. The flourishing natural sciences, based on the interplay between mathematical rationality and empirical observation, furthered the development in both directions. In this manner, de Groot, Pufendorf, and Thomasius undertook to construct a system of eternal, immutable rules of natural law which could be derived from the ultimate axioms of human nature by the mathematical deductive method. The empirical tendency was found in Locke, Hume, and others. Yet both currents initially showed a good deal of similarity, especially in method. The more concrete rules in the detailed natural law system of de Groot were not derived from human nature according to the a priori method, but according to the empirical method, and hence a posteriori. Conversely, Hobbes forced the empirically observed phenomena into a deductively derived system which he had constructed along geometric lines.

Postmedieval empiricism and rationalism in the concepts of natural law corresponded typically to man's dualistic attitude with respect to nature. Man still experienced nature as a reality withdrawn from man's controlling power, whose laws he could merely discover. But it was soon realized that a knowledge of these laws would enable man to start dominating nature. Through these developments natural law in its secularized form began to flourish during the seventeenth and eighteenth centuries. The writers of this time were less mindful of God as lawgiver and author of the natural law; but they continued to adhere to the conviction that an immutable order prevailed in the universe. Still basing themselves on this latter notion, they thus attempted to invest the evolving social conditions with a stable foundation. Man's technical ability was still in its infancy. With the progression of its

7. Cf. J. Mrkkes, Ontwikgelingen der humanistische RechtsstaAtstheorieËN 139-575 (1940). 
development nature lost its normative character and became in the nineteenth century a matter of an empirically determined regularity.

When therefore the scientific development which had started in the sixteenth century reached a flourishing stage in the nineteenth, the law was interpreted pretty well from the standpoint of man's control over the world. Now that the one-sided mathematical apriorism of Descartes had been adapted to experimental observation, the aprioristic systems of law lost ground to the empirical modes of thought. Positivism began to prevail. One only needs to think of the theories of law inspired by sociological, utilitarian, and materialistic doctrines. Legal positivism reduced natural law to the level of a logical, technical category which virtually could be associated with any material content. The magical element which formerly had been frequently attributed to the order of nature was now attributed to the scientific concept of law, and this in turn led to the ideology of progress.

Although man himself now undertook to create order and to render the world of nature more and more artificial, he still lived under the illusion that there existed a permanent order which could be gradually and scientifically discovered and put to use. However, this order was no longer experienced as possessing a normative character, but as an empirically observable fact. These speculations began already to anticipate the later development of decreasingly viewing nature as a given reality which man was expected to obey. Only in retrospect did philosophical thinkers discover the transformations which already had been brought into practice in man's technical actions. During the twentieth century, the realization was born that man himself creates order by means of his technical power and that a permanent order as an objectivistic independent world, a monde-en-soi, is nonexistent. 8

Contemporary thought, becoming aware of the metalogical and metarational; takes a stand against the distorted rational and logical attitude of the preceding centuries. The natural sciences particularly emphasize this change. Classical physics was founded on the idea that the laws of nature, which man discovered, were objective realities. Contemporary physics realizes that man is not an objective observer, but that he himself remains present in the concepts whenever he approaches nature. The goal of the natural sciences is no longer "nature in itself," but nature as approached by man, in which approach the natural scientist himself also plays his part. Even in the most exact science the word "nature" assumes a less objective and given character. Von Weizsäcker writes: "Perhaps the most im-

8. Cf. J. de Valk, De Evolutie van het Wetsbeorip in de Sociologie 132-137 (1960). 
portant intellectual contribution of contemporary physics is the discovery of the necessity to consider the interrelation of matter and consciousness, of object and subject, in a different light than it was conceived of in the philosophical tradition of the last century."9 Bacon's idea that man must first observe nature as a neutral onlooker in order to be able to subsequently utilize it, is closely bound up with the concept of a given objectivistic independent world, a monde-en-soi, which is not tenable. Science is less the progression from one certainty to the next, as the reflection of an immutable natural order, than the revealing of a reality in the construction of which man has always played his part, a reality which recedes like a horizon with every objectivation.

According to the rationalistic conception of the preceding centuries, scientific knowledge constitutes the thesis, and the as yet unknown factor $\mathbf{X}$ the hypothesis. Strictly speaking, modern science now poses the thesis that reality will always transcend human reason and that all scientific endeavor is merely hypothetical, i.e., it bears a tentative character, and its results will have to be continually altered. There is no given natural order existing from eternity, whose laws science attempts to trace. Nature begins to assume the character of an object to be employed in the service of man creating order. That which is natural in the sense of the orderly now becomes that which is artificial. Planning supplants the naturalistic principle of laissez faire. But with this rising power grows a new impotence. Man becomes aware that he may fall victim to the impersonal powers and organizations which he himself has created. Powerlessness against the technical world has replaced powerlessness against the world of nature. It is being more and more realized that the essentially human qualities cannot be made by man, but are received as a gift. The ideologies which believed in an economic and technical order that creates happiness have lost favor. The law of life does not lie in the power motif, but in the surrender to and the respecting of the other person. The new security will be found in interhuman relationships which are not purely the result of human achievement.

Against the background of these revolutionary changes in the technical, natural world-view the shifts in emphasis regarding the natural law as a normative criterion of human actions can now be understood. We are not any longer primarily concerned with a natural order, but rather with a personal one. The norms are not vested in the immutable laws of a worldorder seen through the eyes of physicists, but they are vested in the immutable

9. Physik der Gegenwart 11 (1953). See A. Kockelmans, Eenheid en Verscheidenheid in de Wetenschap volgens het Standpunt der Phaenomenologie, 22 TIJpscaript voor Philosophie 343 (1960). 
value of the human person. This means a shift in ideas from a static morality of duty to an ethics of the ideal. When the natural law was still the reflection of a stable social pattern, the meaning of human life was, so to speak, made objective and circumscribed in social morality and customs. Ethics then placed a strong stress on man's dutiful and conforming adaptation to the given social ethos. Personalist ethics today shows a greater awareness of the intrinsic value of the person in the capacity of designer of his own life, and does not envision natural law primarily as a series of set tasks, but as a charge and a calling. Contemporary ethical consciousness appeals much more to the responsible selfcommitment of each human being. Self-development means first of all the creative surrender of self to one's fellow men. The ethical élan is not directed towards adaptation to a static natural community, but towards the dynamic construction of the ideal personal community. The new task then is to make my fellow man-and, by implication, myself- "be" in the fullest ideal capacity, within the framework of a supraindividual community of persons.

The world of technocracy is permeated with brotherhood and companionship. Man no longer encounters his fellow men indirectly in a commonly owned and understood nature, but he virtually must rely on the other person for the very development and cultivation of this world. One cannot deny that the values of love, respect, admiration, and loyalty are acquiring a more profound significance in our time. Whereas primitive men were captivated by the spell of the unknown, mythical forces of nature, and man during the rationalistic period manifested a magical admiration for a rational worldorder, it is now man's personal dignity which constitutes a new source of ethical inspiration. 10

Love and respect for the irreplaceable and eternal values inherent in every person invest contemporary natural law with a greater spiritual content. Natural law is no longer one-sidedly understood as a given factual order, but rather as a spiritual entity, which is not imposed from the outside as an object, but which reveals itself in sincere intrapersonal contacts. In the personalist conception this "supernatural" ethics of natural law is preferably called the ethics of values. In this personalist ethics the biological and psychic aspects of the person remain as a given natural aggregate which sets its own normative standards. But this given aggregate is absorbed in the totality of the person whose being is not a given entity, but rather a charge. It is exactly each person's primary task to spiritualize these corporal aspects and make them part of his personal, free existence. The personalist vision does not see man's corporal nature in the first place in its character of object, but

10. Cf. J. J. Loeff, op. cit. supra note 6, at 37-50. 
rather as a concrete expression and actualization of an all-pervading love.

The traditional natural law theory was implicitly founded on the idea that man lived in a world of immutable and supratemporal entities, from which the ethical norms could supposedly be deduced. This undoubtedly fitted into the cultural vision of those days, but this pattern of society has been outlived. Within the framework of the contemporary cultural development, with its acute awareness of man's involvement in history, such a concept of the natural law makes a conservative and unrealistic impression. It formalizes the ethical consciousness, particularly in its external phases, and applies the rules of the natural law too much in terms of theoretical axioms. Every objectivation, including the objectivation of morality in the law, is abstract-universal. That is why the ethical ideal, through a one-sided objectivating approach, easily fades into a colorless uniformity of a minimized set of norms valid for the average man. If concrete ethical living is too largely a practicing of a scientifically developed theory of the normal, then the sense of personal responsibility weakens and easily leads to an unauthentic performance morality. Undoubtedly objectivation in terms of standards and norms remains a valuable facet of ethical conduct, but this aspect must not be exaggerated. Personalist morality speaks in terms of value rather than of natural law. It emphasizes that the ethical reality must not be employed as an "object at hand." We are concerned here with an existential reality. The ethical values pertain to persons. Ultimately, moral truth is not an object, but a subject. It is for this reason that sacred scripture states: "I am the Way, the Truth, and the Life."

\section{The Natural Law in Jurmigal and Ethical Perspective}

As IS THE CASE with human life, the cultural pattern of a society constitutes a totality of meaning in which the various aspects of life interpenetrate and mutually influence one another. Contemporary personalist society manifests the tendency towards an ever-richer differentiation of the different levels of life within the framework of an ever-growing unity and integration. Thus, the realms of law, ethics, and religion, for instance, in their increasing independence are actually growing more mutually dependent upon one another. Here unity and distinction, integration and differentiation go hand in hand. Between the various levels of life one cannot make univocal specific distinctions. Jurisprudence is not something totally different from ethics. We are dealing here with an analogous distinction within the unity of the structural totality. Jurisprudence has its own sphere; but the more the legal order achieves its own perfection, the more it transcends itself in pointing to the realm of ethics, 
without ever becoming ethics. The same situation prevails with respect to the ethical dimension. To the extent that the ethical attitude asumes its own perfection, the more it transcends itself, without ever becoming religion. When a certain phase becomes mature, it then truly is a "phase," i.e., it particularly points to the next higher one. ${ }^{11}$

Two important conclusions result from this mysterious simultaneity of unity and differentiation, insofar as the ethical and the legal dimensions are concerned. If the legal sphere ignores its élan towards ethics, it cannot itself flourish. Law then involuntarily draws ethics into its own sphere, with the result that the legal order will be absolutized ethically. Conversely, if the ethical order does not respect the inherent value of the sphere of law; this will lead to a degeneration of ethics. Ethics then will in turn identify itself easily with law, and the ethical consciousness will assume the appearance of what is outwardly and socially proper and enforceable.

When during the preindustrial era man was still familiar with a stable pattern of life, the legal and ethical dimensions were far less distinct. The same categories of natural law and positive law were employed for both aspects of life. This mutual identification was possible because the natural law was understood as a totality of general normative rules, founded on a traditionally given natural order. In this static society the norm was characterized by regularity, and what was regular assumed a normative character: Thus the concepts of the natural law could be quite univocally understood and applied in ethics as well as in law. In our dynamic society this traditional pattern of existence has been outlived. In ethics as well as in law the natural law must be interpreted less univocally and more analogously. This has not always been done. The result for the realm of law was that an established social situation frequently was considered as ethically absolute. Let us remember, for instance, how difficult it was to accept changing relations in regard to ownership or questions of social security. Social progress was often arrested in the name of the immutable natural law. Ethics, which in turn incorporated a strong legal strain, came to be at the service of what was socially proper, and ethical precepts were far too unauthentically lived.

In the present period of growth the natural law is distinguished analogously in the realms of ethics and law. In an ethic oriented towards the person the natural law becomes a more existential reality, which can be expressed only in ideal-concepts. It appeals to the authentic choice of man, who, from his very being as a person, must fashion a concrete universal image of man, more in the manner of a creator than of a conformist. It is precisely this spir-

11. Cf. J. Peters, Do Gelooige, het Probleem voor de Wijggeer, 47 Annalen van het ThrymognootsGeap 270-77 (1959). 
itual, ideal nature that deepens the laws of physical nature, since it is man's corporal nature which makes its demands exactly as an incarnate spiritual reality. Natural law interpreted in terms of persons emphasizes more the normative and less the ruling character of law. It poses the personalist ideal as being normative, the ideal which man should fashion individually out of his unique and, hence, concrete-universal, intrinsic personal value. It does not take as its point of departure a set of fixed rules; that is to say, it does not pose first and foremost a general and uniform image of man, although this image has its place because of the quality of "species" which belongs to man as an incarnate being.

The sphere of law, on the contrary, places greater emphasis upon the uniformly fixed rules of the natural law and attempts to effect the personalist ideal in the world of space and time. Because of this element of practical application, the natural law of this legal dimension possesses another, although not totally different, color. The personalist strain of ethics renders law itself more functional. Law's content of rules is seen not so much as dependent on a natural static order but as possessing a dynamic, functional character because of its active orientation towards the ideal personal community. Law, then, originates less from an observed natural regularity; it is not so much customary law. On the contrary, it attempts to create regularity, and through this becomes law-creating law. It is in this way that the basic rights formulated constitutionally-being natural law in legal perspectiverender the personal values applicable in terms of generally valid rules. By virtue of its essence this natural law requires elaboration in specialized legal regulations in order to create for the moral ideal a frame of reference which is at once as enlargeable and as ingeniously structured as possible.

However, in distinguishing betwen the natural law in terms of ethics and law, the unity of human existence must be adhered to. One must continue to visualize ethics and law as an inseparable dual unity.

This article has dealt with some shifts in emphasis and interpretation in contemporary ethical thinking. Currents of modern philosophy have made substantial contributions to ethics, whatever exaggerations they have entailed. Those who are concerned about the present ethical climate should have confidence in the natural law which they themselves want to defend. Did not St. Thomas teach that the natural law is, first of all, the spontaneous insight into good and evil, an insight naturally given to every man as a gift of God? The natural law has been engraved in the heart of man - in his heart and not in his scientific intellect. 